\title{
Prevenção às DST/Aids: design da informação para promoção da saúde
}

\author{
STD/AIDS Prevention: information design to health promotion
}

\author{
Ranielder Fábio de Freitas, Hans da Nóbrega Waechter, \\ Solange G. Coutinho
}

design da informação, DST/Aids, impressos, promoção da saúde information design, STD/ AIDS, printed materials, health promotion

\begin{abstract}
Este estudo tem como objetivo descrever se a interpretação das mensagens pelos receptores no processo comunicacional em materiais impressos, com a temática de prevenção às DST/Aids, instigam a promoção de comportamentos saudáveis e/ou aquisição de conhecimentos preventivos. Para isso, buscou-se: a) elicitar aspectos relevantes, sob o prisma do design da informação, inerentes ao conteúdo dos informativos; e, b) descrever a eficácia no uso dos elementos dos modos de simbolização da Linguagem Gráfica nas mensagens, na perspectiva dos receptores. Deu-se foco na variável dos 'efeitos' causados pelas mensagens nos receptores da informação. Assim, os Grupos Focais foram usados como metodologia para interação com os receptores, por meio de um instrumento que aborda os aspectos relacionados aos impressos. Em termos gerais, com algumas ressalvas, as variáveis para compreensão da operacionalização da relação entre os elementos da Linguagem Gráfica no planejamento e desenvolvimento das peças gráficas foram abordadas com parcimônia, possibilitando assim, equilíbrio no uso de seus atributos para cristalização de conhecimentos e adequação de novas condutas pelos receptores frente à prevenção das DST/Aids.
\end{abstract}

The aim of this study is to describe whether the manner in which receivers interpret messages in the communicative process in printed materials, with the theme of STD/ AIDS, encourages behaviour that promotes a healthier outlook and/or the acquisition of knowledge regarding prevention. For this, we have sought to: a) identify relevant aspects, from the perspective of information design, inherent to the content of information, and b) describe the effectiveness of the modes of symbolization of the graphic language in the messages, from the perspective of the receiver. Focus was placed on the variable 'effects' caused by the messages on the information receivers. Thus, Focus Groups were used as a method for interaction with receptors by means of an instrument that concentrated on aspects related to printed materials. In general terms, and with certain exceptions, the variables for understanding the operationalization of the relationship between the elements of the Graphic Language in the planning and development of the printed materials were used very sparingly. Thus, it was possible to achieve a balance in the use of their attributes for crystallizing knowledge and encouraging new attitudes in the receivers regarding prevention of STD/AIDS. 


\section{Introdução}

A promoção da saúde pode ser entendida como o processo de capacitação da comunidade para atuar na melhoria de sua qualidade de vida e saúde, incluindo uma maior participação no controle desse processo (BRASIL, 2002, P.19-20).

Os Programas de intervenção, em destaque os de prevenção às DST/ Aids, buscam sensibilizar os grupos e indivíduos para que atinjam um estado de completo bem-estar físico, mental e social. Assim, utilizam-se das chamadas ações de Informação, Educação e Comunicação (IEC) para efetivar seus objetivos.

Tais ações têm a 'informação' como base para socialização de saberes preventivos nos indivíduos e grupos por meio da utilização de tecnologias estratégicas instrumentalizadas por artefatos diversos, tais como os impressos (folders, álbuns seriados, cartazes, etc.).

Desta forma, essas estratégias possibilitam uma aproximação das vivências dos indivíduos em situação de risco com informações qualificadas que instiguem a adoção de comportamentos preventivos em relação a essas doenças e a Aids,fortalecendo os métodos de promoção à saúde. (SESDF, 2012).

Considerando os artefatos impressos como inerentes à prática do designer, destaca-se a necessidade da aproximação do Design da Informação.Sendo uma área do conhecimento que surge destinada à configuração do conteúdo dos Sistemas Informacionais (SIs) com fins a efetivar a eficácia e eficiência destes, aumentando sua compreensibilidade no diálogo entre os sujeitos no processo comunicacional. (COUTINHO, 2006).

Por vezes, é possível identificar artefatos sob a temática aqui apresentada, com potencialidades de representar polissemias informacionais em seu conteúdo verbo-visual. Além disso, configurados de forma que os atributos sintáticos dos elementos gráficos utilizados gerem estresse congnitivo, fazendo com que os receptores sintam-se infantilizados ou se distanciem do assunto tratado com a realidade da cultura vigente (figura $1 \mathrm{e}$ figura 2). 



Figura 2 : Doenças Sexualmente Trasmissíveis. O que são e como prevenir (Folder, Visão Externa) Fonte: Biblioteca Virtual em Saúde, Ministério da Saúde
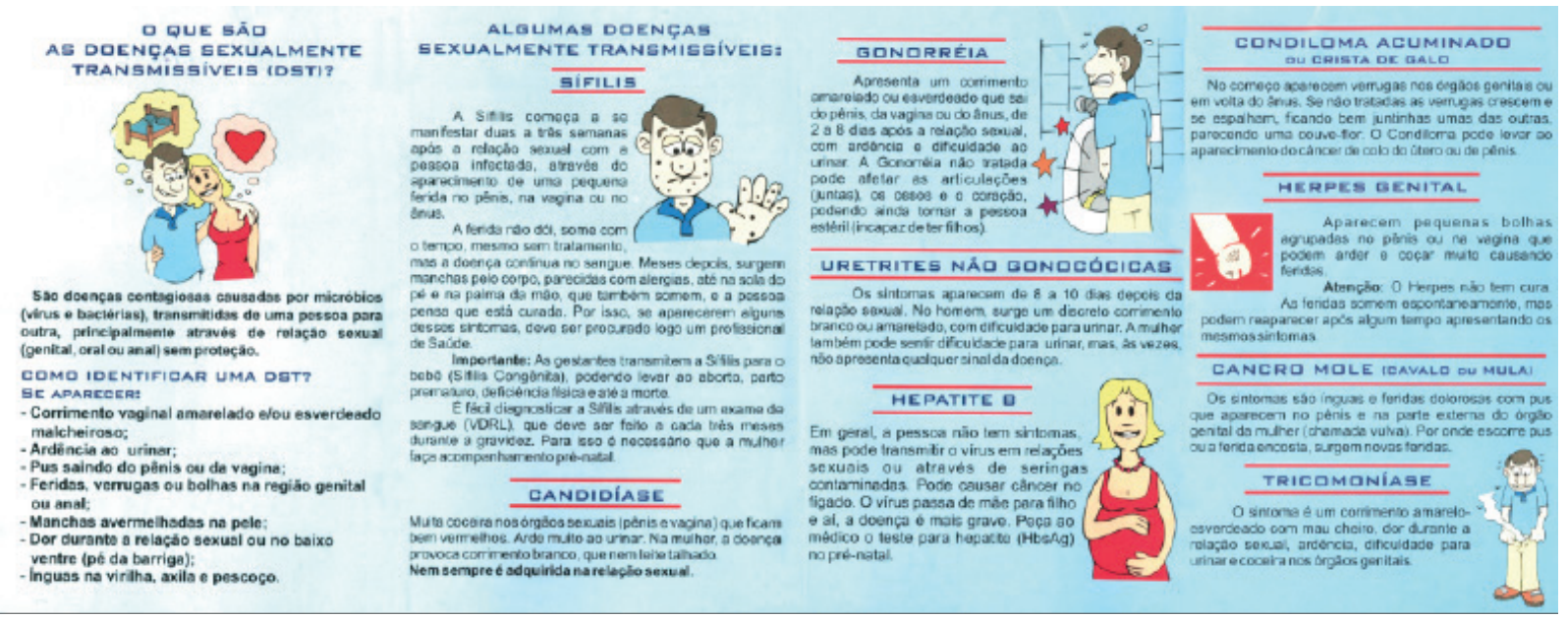

Figura 1 : Doenças Sexualmente Trasmissíveis. O que são e como prevenir (Folder, Visão Externa) Fonte: Biblioteca Virtual em Saúde, Ministério da Saúde

Sendo assim, o Designer da Informação pode agir como mediador entre o conteúdo e o receptordessas mensagens, considerando seus princípios norteadorese aspectos de contextos variados. Integrando tambémtécnicas interdisciplinares e o próprio receptor para este fim (design colaborativo).

Sob essa perspectiva, o receptor deve sentir-se possuidor da informação, ou seja, deve compreender, de forma clara e com o mínimo de esforço, possibilitando que suas redes de interrelação imagética exerçam suas atividades de forma eficiente.

Frente às afirmações, Rozemberg (2012) considera imperativo implementar iniciativas de avaliação da apropriação dos significados e da eficácia informacional contida nestes artefatos. Pois, como relata Santos (2003), ainda são escassas ações que avaliem o real impacto das mensagens contidas nos discursos destes.De que forma é apresentado o conteúdo verbo-visual desses artefatos? Quão eficiente mostram-se os elementos que os compõem? 
Com isso, supõe-se que um conteúdo verbo-visual bem projetado e que atenda as especificidades de grupos em situação de risco, instigue práticas saudáveis frente às DST e à Aids, contribuindo para compreensão do conteúdo e efetivando seu propósito comunicacional.

Diante das considerações, o objetivo geral deste estudo é descrever se a interpretação das mensagens pelos receptores instiga a promoção de comportamentos saudáveis e/ou aquisição de conhecimentos preventivos. Tal objetivo será alcançado por meio dos seguintes objetivos específicos:(a)elicitar aspectos relevantes, sob o prisma do design da informação, inerentes ao conteúdo dos informativos, e; (b) descrever a eficácia comunicacional dos elementos da Linguagem Gráfica (LG) das mensagens, na perspectiva dos receptores.

\section{Algumas considerações pertinentes}

Esse estudobuscou uma breve relação com a Retórica, a qual pode ser usadacomo estratégia para reforçar a mensagem e direcionar a intenção comportamental das pessoas para sensibilização da prevenção das DST/Aids (вONSIEPE, 2011, P. 145-146); com as Sequências Pictóricas de Procedimentos (SPP), as quais compreendem representações de procedimentos por meio de imagens (SPINILlo, 2000), ecom a Linguagem Gráfica, entendida como veículo de comunicação que comporta tudo que é gráfico em resposta a decisões conscientes, sendo representada, essencialmente, na forma bidimensional. (TWYMAN, 2002).

Neste caso, refere-se à Linguagem Gráfica em seus modos de simbolização: Linguagem Gráfica Pictórica (LGP) representada por figuras, desenhos, fotos, etc.; Linguagem Gráfica Verbal/Numérica (LGV), que engloba palavras e símbolos alfanuméricos, assim como suas variáveis de configuração; e, Linguagem Gráfica Esquemática (LGE), que se relaciona com elementos não-verbais ou não-pictóricos, geralmente usada em conjunto com as outras duas (linhas, box, esquemas, etc.) (silva \& COUTinHo, 2010).

Para contextualizar a coesão das imagens, Goldsmith (1980) é convocada com seus pressupostos acerca da possibilidade da linguagem pictórica não comunicar a mensagem intencionada.

\section{Percurso Metodológico}

Estudo de abordagem qualitativa que envolveu a interação pesquisador-participantes e buscou como resultados uma análise fiel de vivências do cotidiano, valorizando o subjetivo e contemplando, como enfoque principal, o ser humano em sua complexidade. (BARDIN, 2009).

Embora tenha-se buscado entender a relação entre a 'intencionalidade' das mensagens e o 'efeito' causado por elas em seus 
receptores, o presente artigo foca somente na segunda variável, na qual os pesquisadores puderam avaliar a relação entre a configuração dos elementos da linguagem gráfica em sua interação com o receptor.

Para tal, foi utilizada a técnica dos Grupos Focais (DALL'AGNOL \& TRENCH,1999), adaptada ao percurso metodológico proposto por Waechter (2008) para guiar as etapas da pesquisa (figura 3).

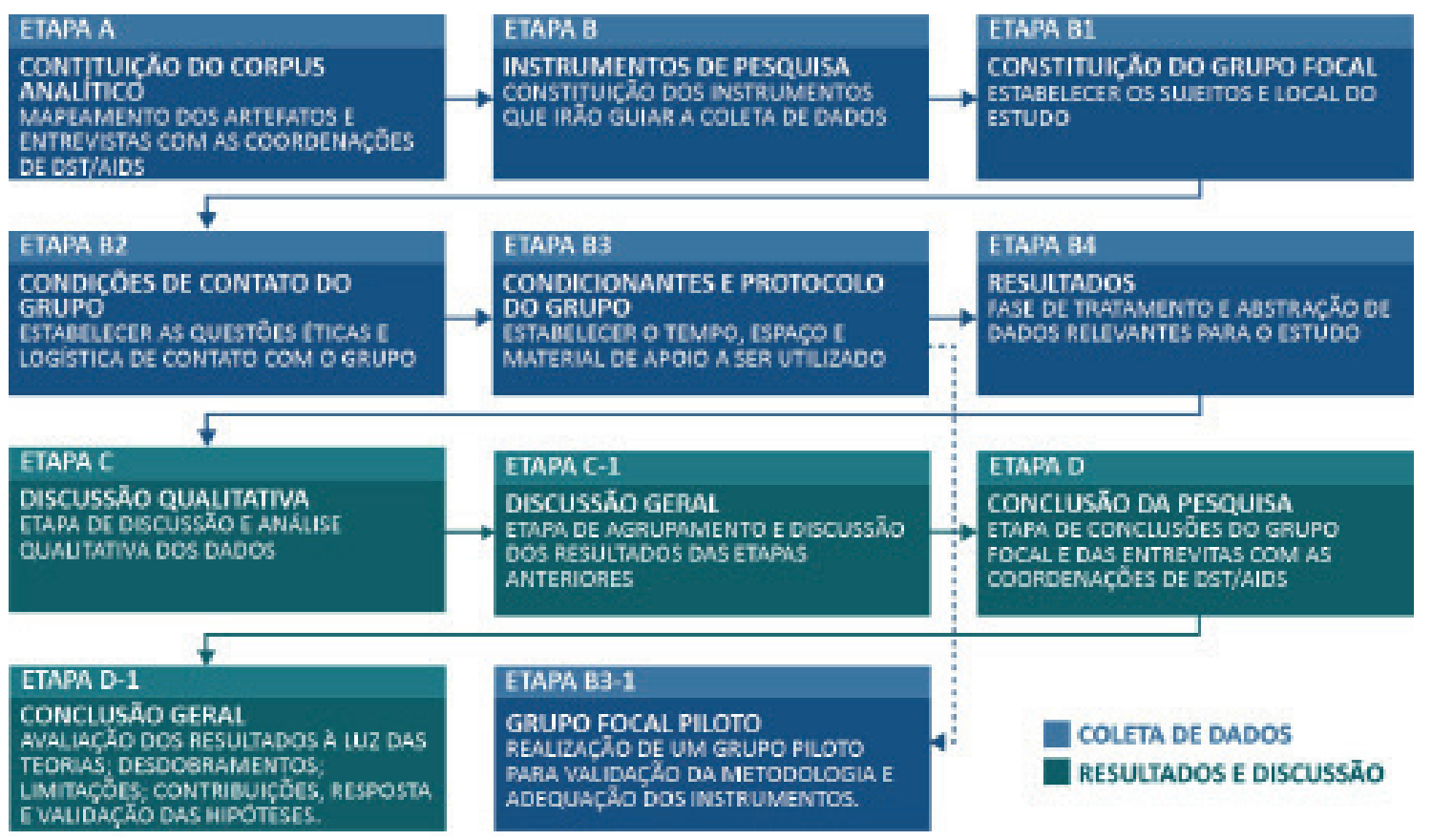

Figura 3 : Esquema do percuso metodológico Fonte: Elaborado pelo autor principal, adaptado de Waechter, 2008

A coleta de dados foi realizada em duas etapas: Etapa A, dedicada ao mapeamento dos artefatos impressos junto a Coordenação Municipal de DST/Aidsdo município de Fortaleza (CM-DST/Aids) eEtapa B, levantamento de informações com jovens universitários, por meio da técnica de Grupo Focal.Salienta-se que artefatos produzidos também pela Coordenação Nacional de DST/Aids (CN-DST/Aids) fizeram-se presentes.

\section{Coleta de Dados- Etapa A}

Este momento oportunizou a coleta dos materiais utilizados no estudo, totalizando 18. No entanto, devido às limitaçõesdeste artigo, serão discutidos apenas cinco, demonstrados a seguir: 


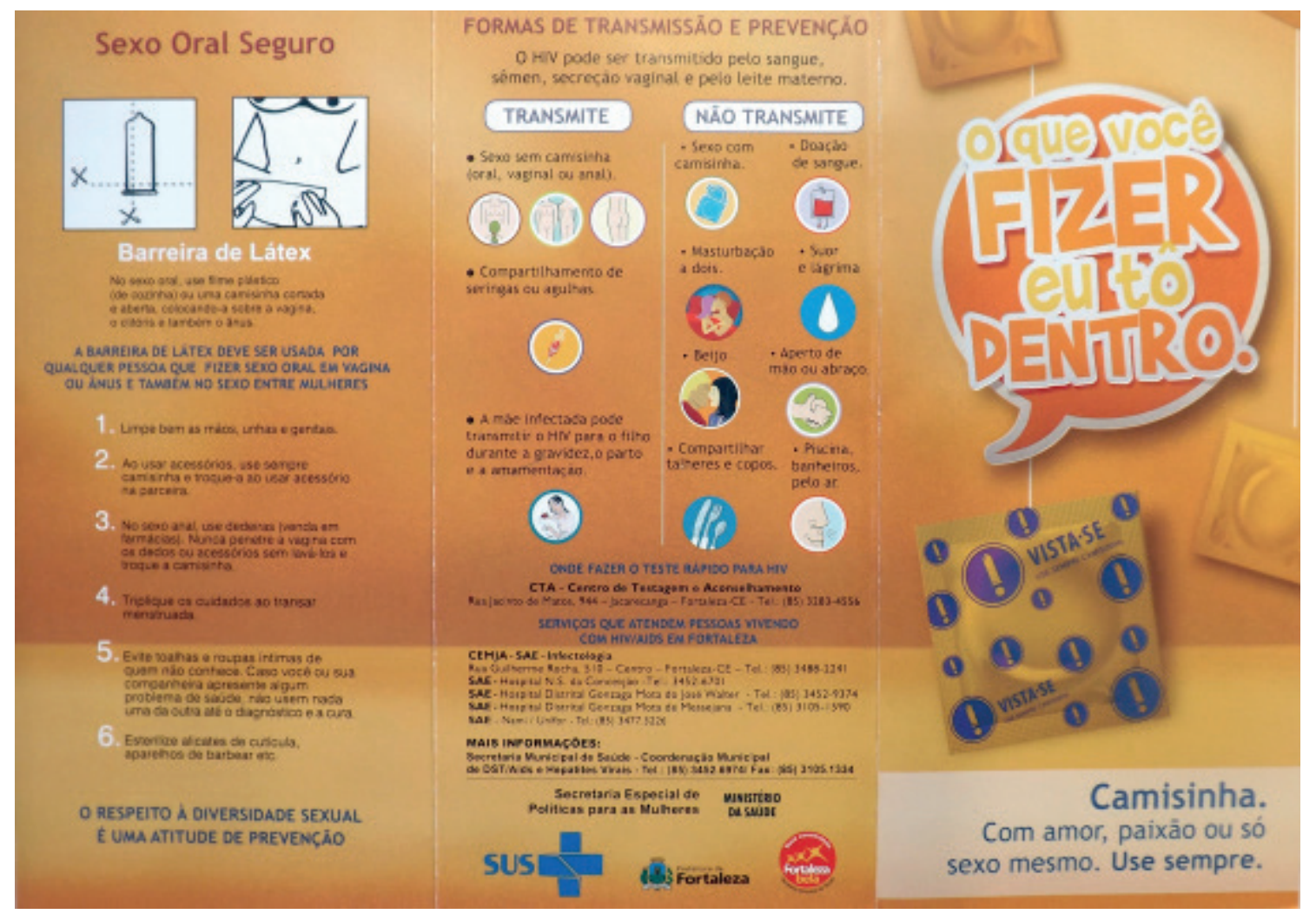

Figura 4 : O que você fizer eu tô dentro (Folder, 2010, visão externa) Fonte: CN/DST-Aids

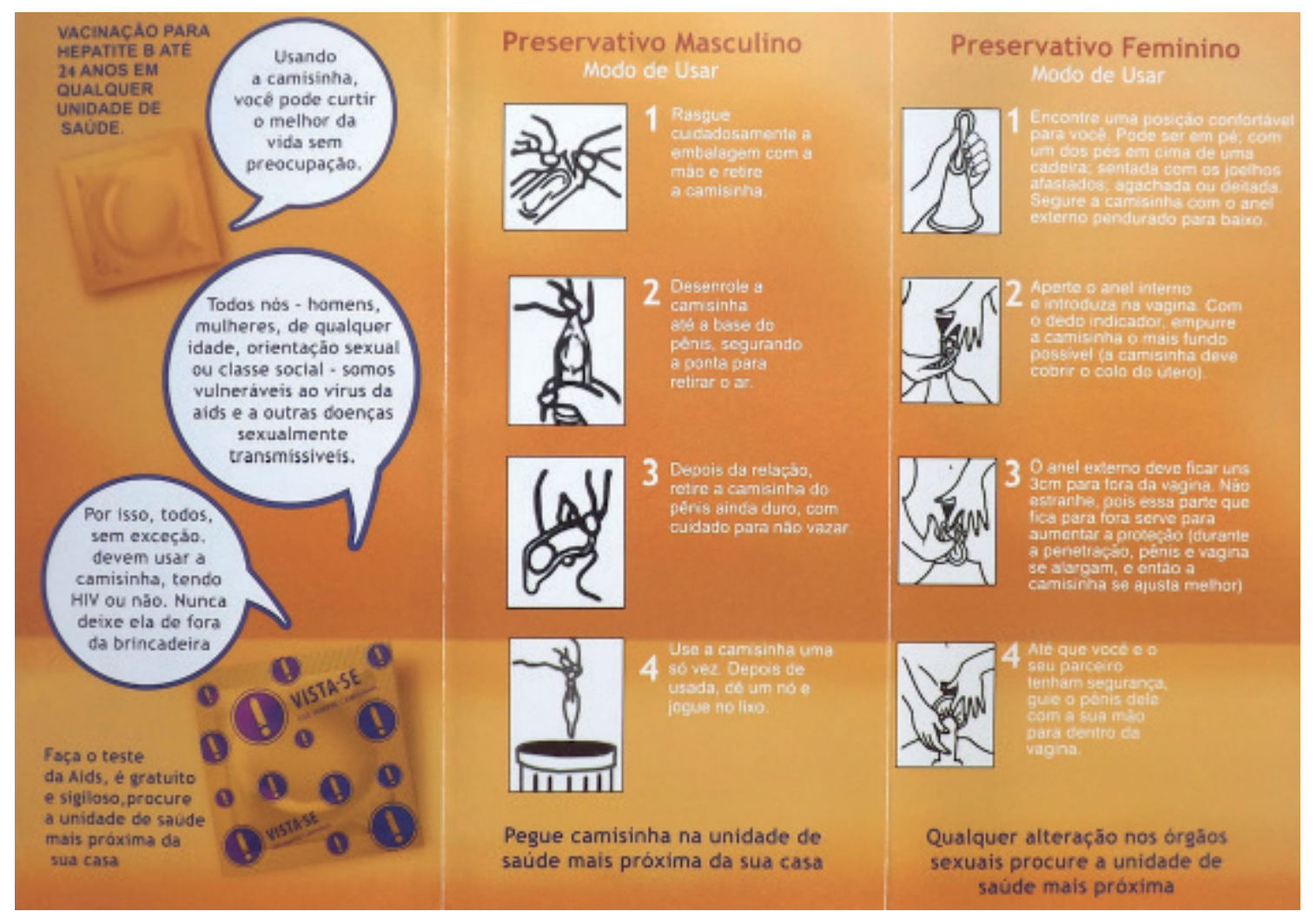

Figura 5 : O que você fizer eu tô dentro (Folder, 2010, visão interna) Fonte: CN/DST-Aids 




Figura 6 : DST: Clube da mulher madura (Folder, 2009, visão externa) Fonte: CN/DST-Aids

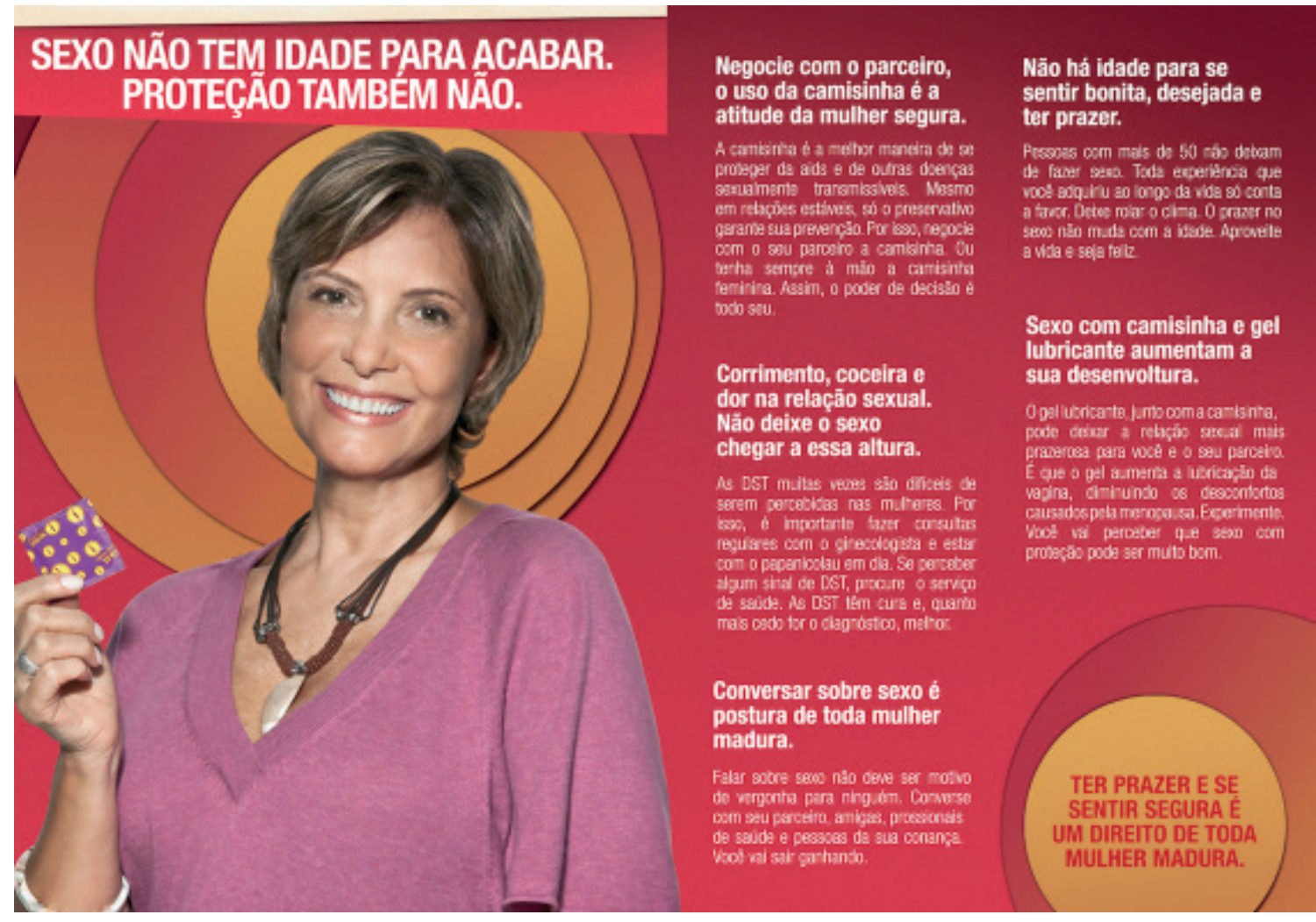

Figura 7 : DST: Clube da mulher madura (Folder, 2009, visão interna) Fonte: CN/DST-Aids 


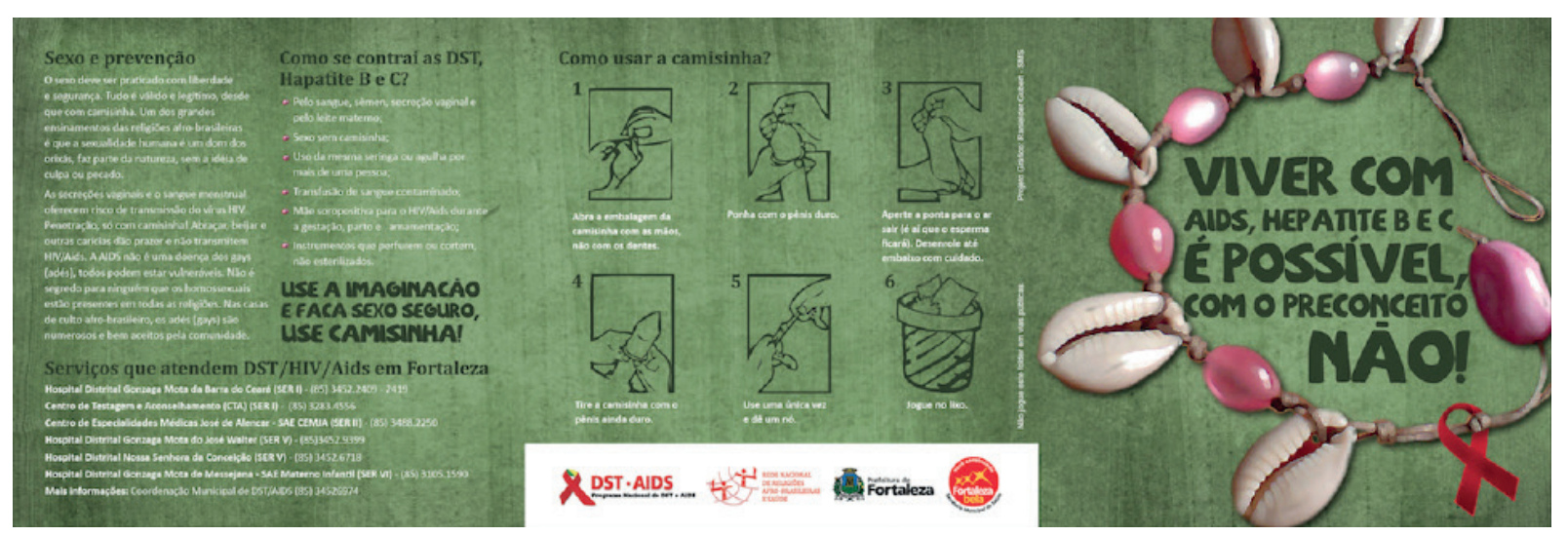

Figura 8 : Viver com Aids, Hepatites B e C é possível, com o preconceito não! (Folder, 2010, visão externa) Fonte: CN/DST-Aids

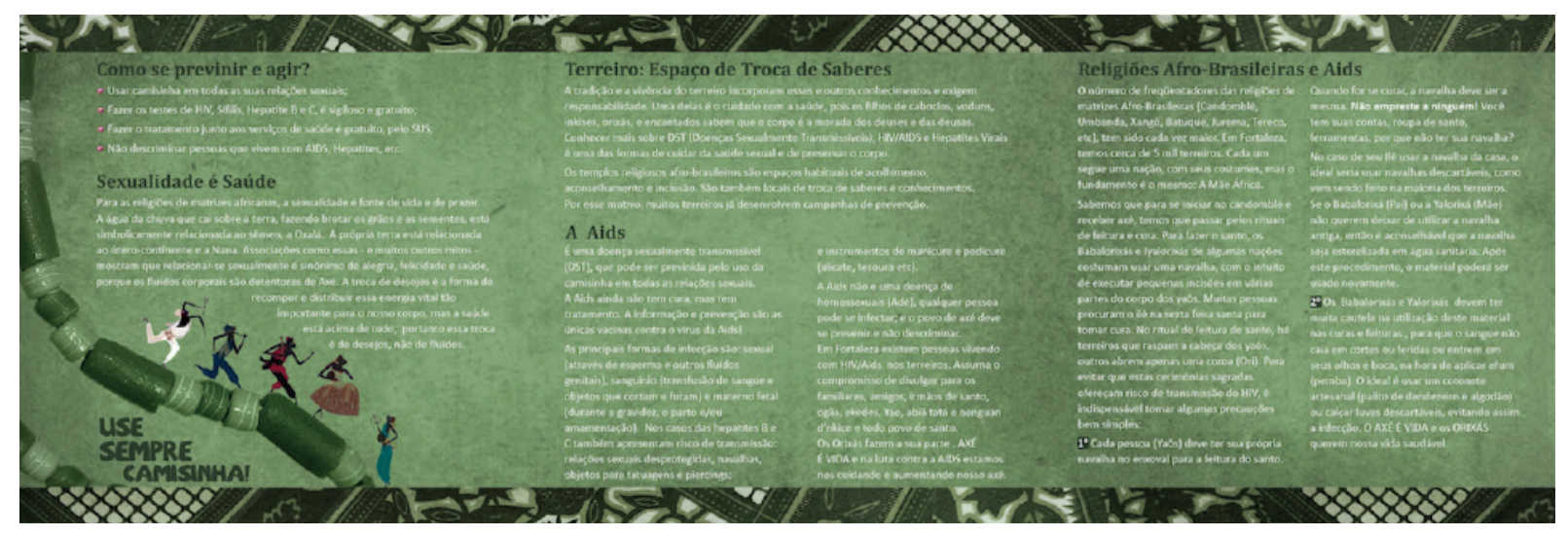

Figura 9 : Viver com Aids, Hepatites B e C é possível, com o preconceito não! (Folder, 2010, visão interna) Fonte: CN/DST-Aids

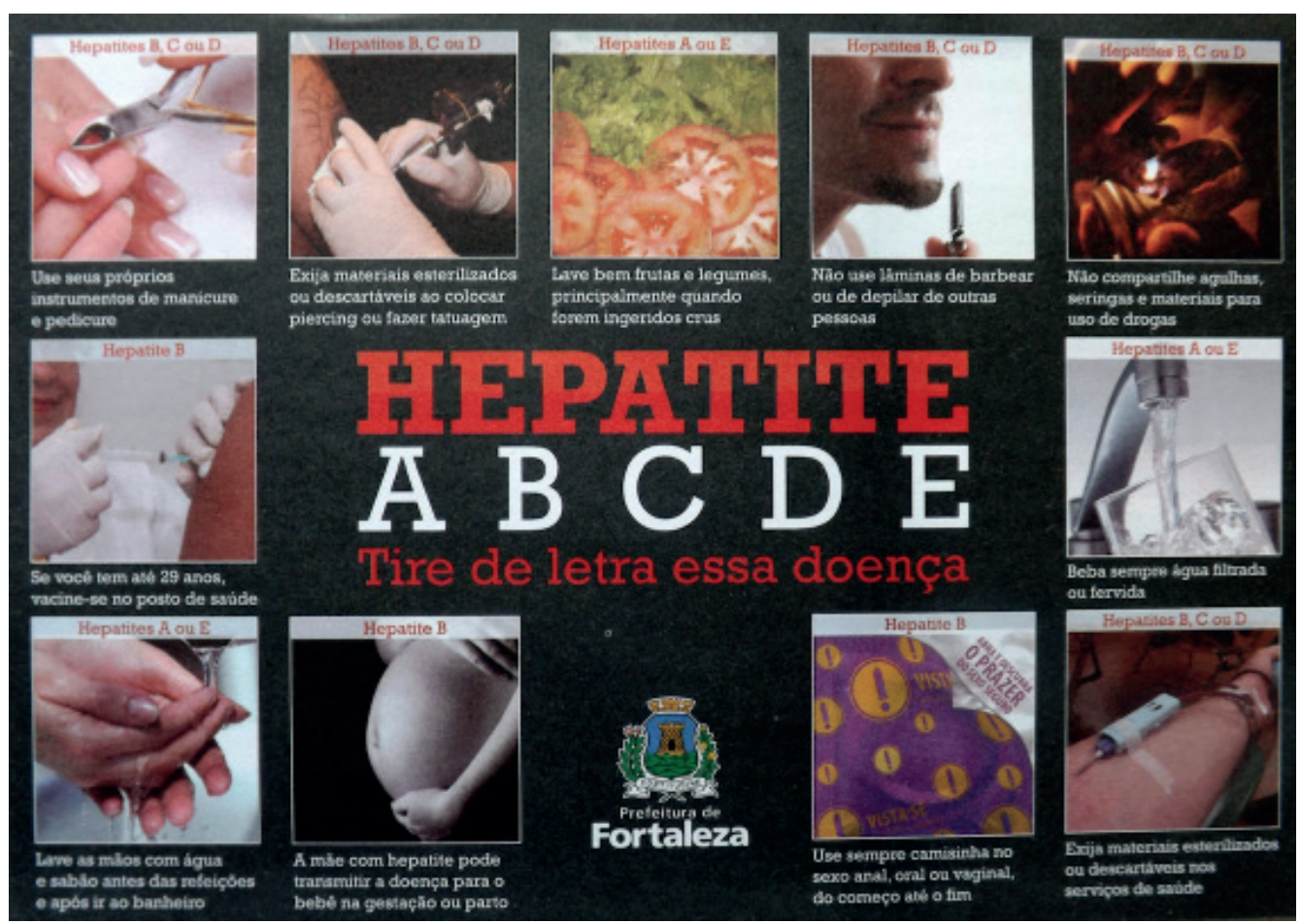

Figura 10 : Hepatite A, B, C, D, E: tire de letra essa doença (Folder, 2008,frente) Fonte: CN/DST-Aids 


\begin{tabular}{|c|c|c|}
\hline  & 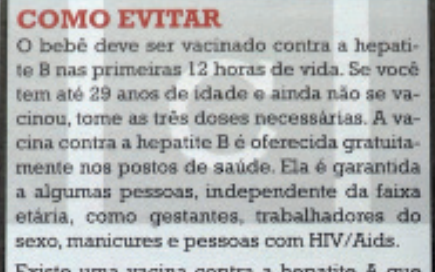 &  \\
\hline $\begin{array}{l}\text { sadas pelos virus } \mathrm{A}, \mathrm{B} \text { e C. } \\
\text { O virus B (HBV) pode ser encontrado princi- } \\
\text { palmente no sangue e eno esperma. O virus } \\
\text { C (HCV) tambèm pode estar presente no } \\
\text { sangue. }\end{array}$ & 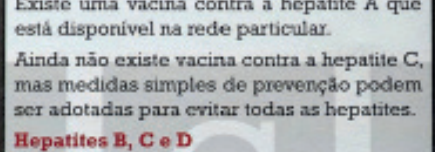 & $\begin{array}{l}\text { ONDE BUSCAR TRATAMIENTO } \\
\text { Hospitais que tratam as hepatites B e C } \\
\text { O Hospital Geral de Fartaleza } \\
\text { Rua Desembargador Lauro Nogueira, } 1 \\
\text { Papicu - (85) } 3101.3222\end{array}$ \\
\hline 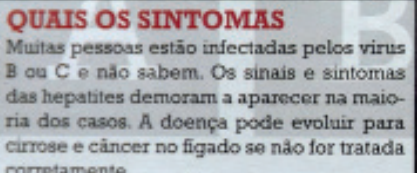 & $\begin{array}{l}\text { Principaia vias de transmissäio: sangue e sexo } \\
\text { - Use sempre camisisinha na relaça sexual } \\
\text { anal, oral ou vaginal, do começo até o fim. } \\
\text { Em qualquer posto de saude, vocé adquire } \\
\text { preservativos de graca. } \\
\text { - Näo compartilhe agulhas, seringas ou ou- }\end{array}$ & 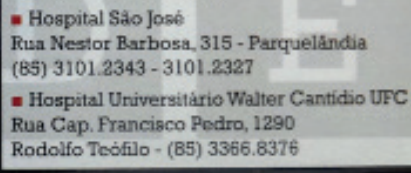 \\
\hline $\begin{array}{l}\text { Somente com exames de sangue detalha- } \\
\text { dos é possivilal saber se a pessoa está ou năo } \\
\text { com hepatite. } \\
\text { - Mal-estar } \\
\text { - Dores de cabeça e no corpo } \\
\text { - Cansaço } \\
\text { - Falta de apetite } \\
\text { - Febre } \\
\text { - Cor amarelada das mucosas e da pele } \\
\text { - Urina evcura } \\
\text { - Fezes claras }\end{array}$ & 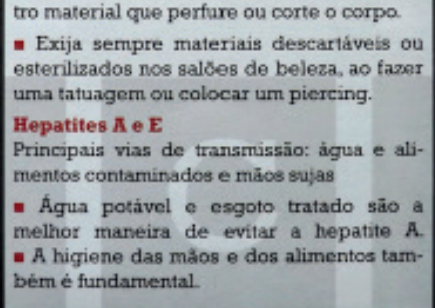 & $\begin{array}{l}\text { MAIS INFORMILÇŌES } \\
\text { Secretaria Municipal de Saúde } \\
\text { Coordenaçäo Muricipal de DST/Aids } \\
\text { e Hepatites Virais } \\
\text { (85) } 3452.6974-3105.1334\end{array}$ \\
\hline
\end{tabular}

Figura 11 : Hepatite A, B, C, D, E: tire de letra essa doença (Folder, 2008,verso) Fonte: CN/DST-Aids
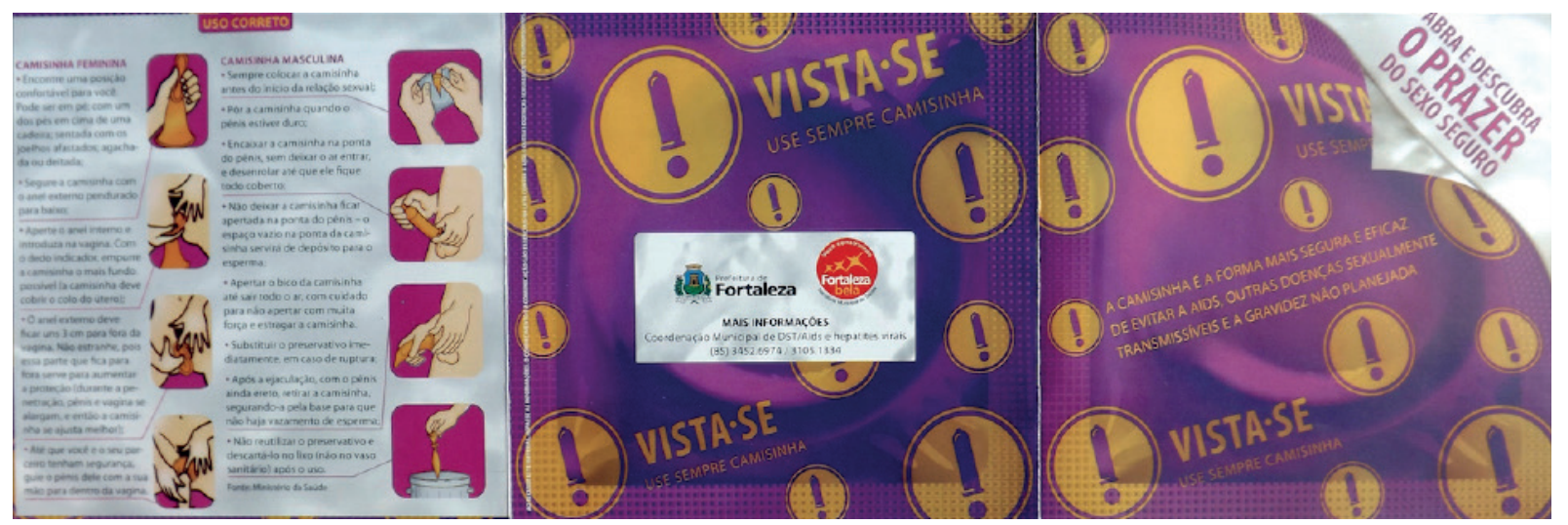

Figura 12 : Abra e descubra o prazer do sexo seguro (Folder, 2009, visão externa) Fonte: CN/DST-Aids
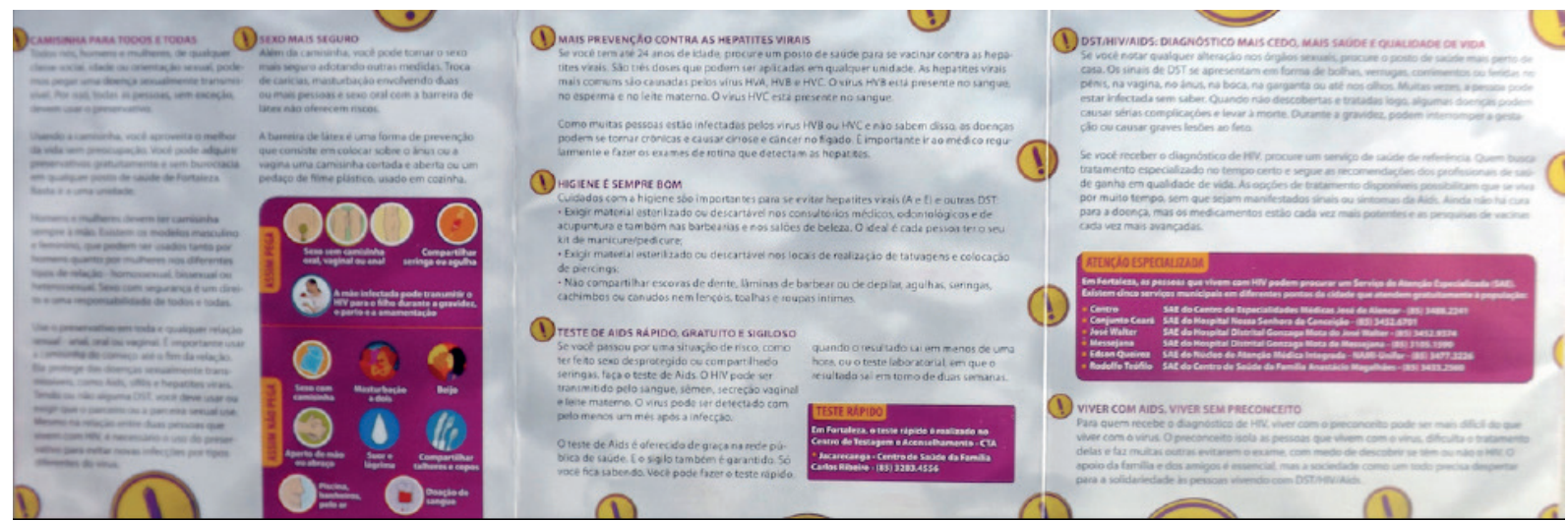

Figura 13 : Abra e descubra o prazer do sexo seguro (Folder, 2009, visão interna) Fonte: CN/DST-Aids 


\section{Coleta de Dados - Etapa B}

Foi utilizada a técnica dos Grupos Focais (DALl'AGNOL \& TRENCH, 1999) para aprofundar-se na relação que os receptores da informação tem com os elementos que compõem os artefatos. Elaboraram-seperguntas norteadoras baseadas no instrumentoproposto por Rozemberg (2012) para guiar a discussão durante as sessões dos Grupos Focais, assim como um questionário físico para possibilitar a coleta de dados dos receptores que optaram por não expressar sua opinião verbalmente.Dessa forma, os encontros abordaram como assuntos, as seguintes categorias:

- conteúdo: o problema em foco (assunto trazido no material); intenções do emissor (explícitas/implícitas); direcionalidade (a quem se dirigem as mensagens dos impressos); seleção de conteúdos (excesso, ausência de pontos fundamentais, dubiedade, incorreções, reducionismo, infantilização do público);

- formato e apresentação: folder, cartilha, gibi, cartaz, fotonovela (adequado ao público ou não?); apresentação (atraente, criativa, esteticamente estimulante ao segmento específico de público?); tipo e corpo das letras (favorecimento ou obstáculo à leitura?); densidade e distribuição dos elementos (uso excessivo, pouco aproveitamento e adequação da distribuição dos espaços entre texto e ilustração);

- questões éticas: se a mensagem segrega ou denigre crenças, valores ou modos de vida de algum segmento social (explícita/ implicitamente) ou acena ao público com possibilidades irreais ou remotas);

- linguagem utilizada: eminentemente técnica, normativa/ imperativa, coloquial, estimulante à crítica e tomada de decisões, ou mista.

\section{Local e sujeitos do estudo}

Participaram estudantes da Universidade Federal do Ceará (UFC) na faixa etária de 18 a 24 anos, por meio da assinatura de um Termo de Consentimento Livre e Esclarecido (TCLE), totalizando a participação de 15 mulheres e 9 homens de diversos cursos.

\section{Análise dos dados}

Por fim, houve a abstração e interpretação dos resultados para a formulação dos achados da pesquisa, validação das hipóteses e concepções teóricas para o campo do Design da Informação, à luz de Bardin (2009), no qual o autor apresenta a etapa de análise de conteúdo em três fases fundamentais: a pré-análise, exploração do material e tratamento dos resultados. 


\section{Princípios Éticos}

Incorporam-se nesta pesquisa os quatro princípios da bioética: autonomia, beneficência, não-maleficência e justiça que norteiam a resolução 196/96 do Conselho Nacional de Saúde, que contêm diretrizes e normas regulamentadoras para pesquisa envolvendo seres humanos, de forma direta ou indireta, individual ou coletiva, sejam elas realizadas por qualquer categoria profissional, no campo biológico, psíquico, educacional, cultural ou social, incluindo o manejo de informações e materiais. (BRASIL, 1998).

Este estudo passou pelo crivo do Comitê de Ética e Pesquisa da Universidade Federal de Pernambuco (UFPE), sendo aprovado pelo parecer 249.794, CAAE 12747113.6.0000.5208.

\section{Resultados e discussão}

Em geral, os impressos mapeados utilizaram-se de um discurso que se propunha ao usuário: a adoção de comportamentos preventivos; esclarecimento de mitos acerca das doenças; sensibilização do leitor frente às pessoas vivendo com Aids, assim como o não autoestigma dessas pessoas; socialização de informações sobre serviços e representação do uso correto do preservativo masculino e feminino, caracterizando estratégias de Retórica. (BONSIEPE, 2011, P. 145-146). Para ilustrar a discussão, propõe-se a adoção da nomenclatura a seguir:

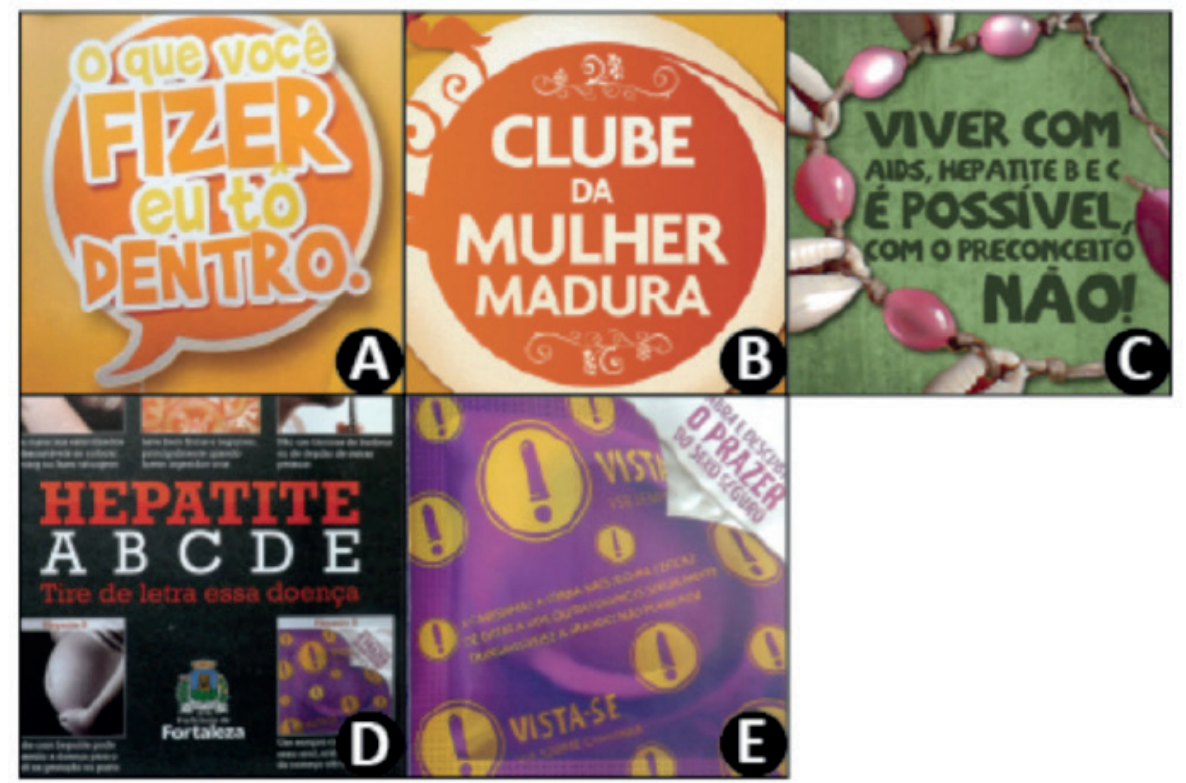

Figura 14 : Legendas dos impressos presentes no artigo (Figuras 4, 6, 8, 10 e 12) 
Os impressos A, C, D e E, mostraram-se carregados de polissemias pictórias, sendo os aspectos sintáticos e semânticos de seus elementos, na visão dos pesquisadores, negligenciados.

Fizeram-se presentes nos artefatos A, C e E, duas SPPs do uso correto de preservativos, sendo uma voltada para os homens (figuras 15, $16 \mathrm{e}$ 17) e as outrasàs mulheres (figuras 18, 19 e 20). A execução da ação foi apontada pelos receptores do sexo masculino como passível de execução, mesmo sendo representada com baixa qualidade sintática (figuras 15).

A SPP a seguir, parece ter sido aproveitada de algum arquivo digital e adaptada ao artefato sem que tenha havido uma melhor acuidade visual em sua apresentação. Além disso, os passos são mostrados sem o cuidado de uma ordenação lógica para ação, ou seja, sem o uso de símbolos que classifiquem a hierarquia com que a ação deva acontecer. O que seria o primeiro passo, utiliza-se de um texto que não justifica sua presença. Seria mais útil seu uso com uma informação de relevância como: "Abra a embalagem com cuidado sem utilizar objetos cortantes."

Olha, esses desenhos estão meio mal feitos, mas dá pra eu ter uma noção do que tem escrito aí e o texto me ajuda. - fala do receptor A

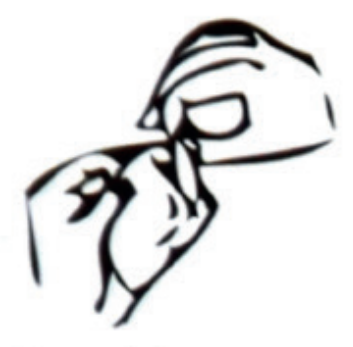

Abra a embalagem da camisinha

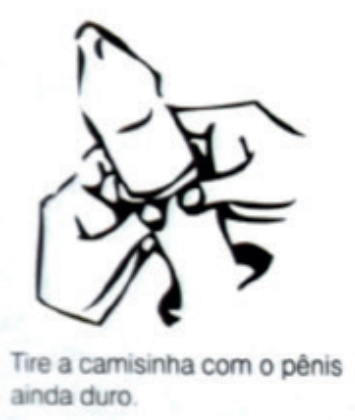

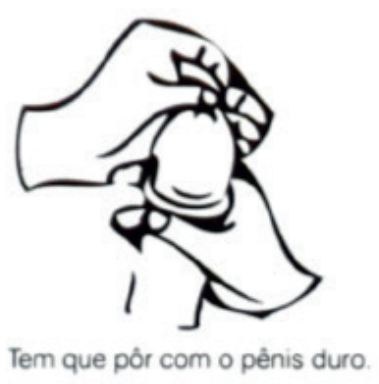

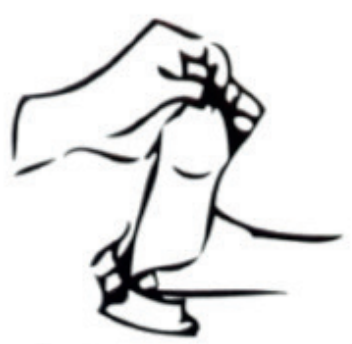

Aperte a ponta para o ar sair (é ai que o esperma ficará). Desenrole até embaixo com cuidado

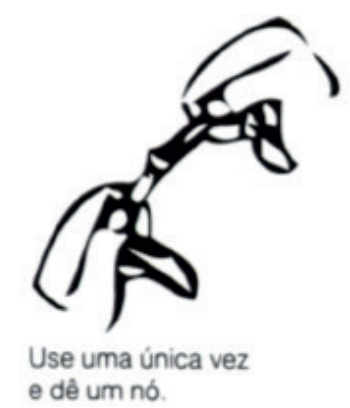

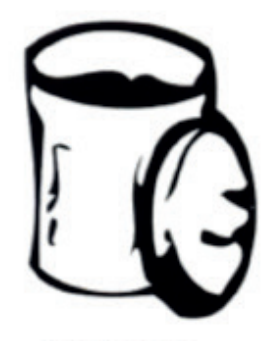

Jogue no lixo.

Figura 15 : SPP do uso correto do preservativo masculino (artefato C) A SPP da figura 15, gerou dúvidas em relação aos traços:

Espera aí [...] nessa figura 2 fala que é para segurar a ponta da camisinha e desenrolar, mas parece que ele tá puxando para o lado contrário [...] é pra puxar ou pra segurar? - fala do receptor $B$

Eu também vi um negócio meio estranho ai mas foi no terceiro passo. Ai tá falando que tem que retirar a camisinha com o pênis ainda duro, mas 
na figura o pênis não parece duro [...] e o que é isso debaixo do pênis? fala do receptor $\mathrm{C}$

Foi unânime quando discutido acerca da possibilidade das ilustrações por si só conseguirem transmitir uma mensagem clara do que deveria ser feito. Ou seja, as ilustrações do artefato A mostraram-se pouco eficientes, mesmo com o suporte verbal.

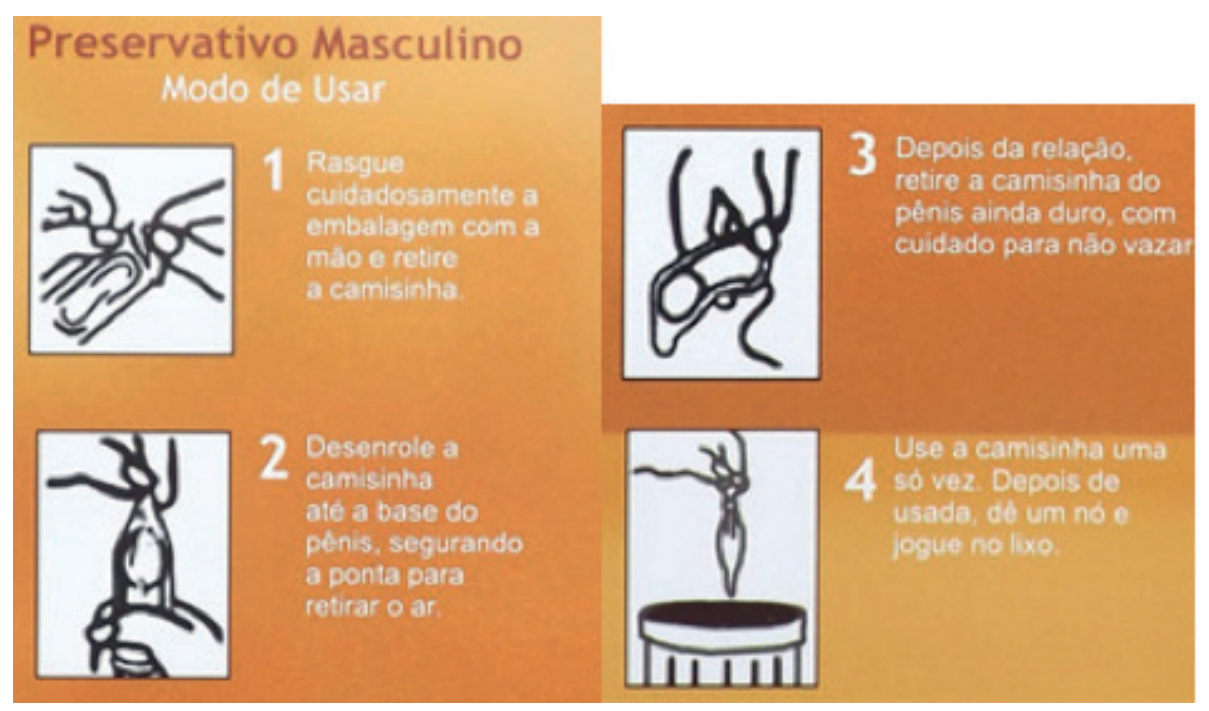

Figura 16 : SPP do uso correto do preservativo masculino (artefato A, disposição original alterada para horizontal)

Situação parecida aconteceu com a SPP do artefato E (figura 16). A melhor definição das ilustrações e o uso de cores beneficiaram a compreensão da ação, no entanto, o texto complementar apresentou falhas de hierarquia informacional, tais como: o uso de entrelinhas de configuração aproximada, e, a caixa de texto do passo anterior, adentra o nível de associação do passo seguinte, dificultando uma melhor relação entre texto e ilustração, buscando essa familiaridade somente com o uso de uma linha. Essa 'fadiga visual' ficou evidente na fala dos receptores:

Esse jeito de mostrar o uso da camisinha tá mais bonito colorido e é mais fácil de entender, mas esse texto tá uma bagunça [...] quando eu leio eu tenho que ficar procurando saber que figurinha ele tá falando. - fala do receptor $\mathrm{A}$ 


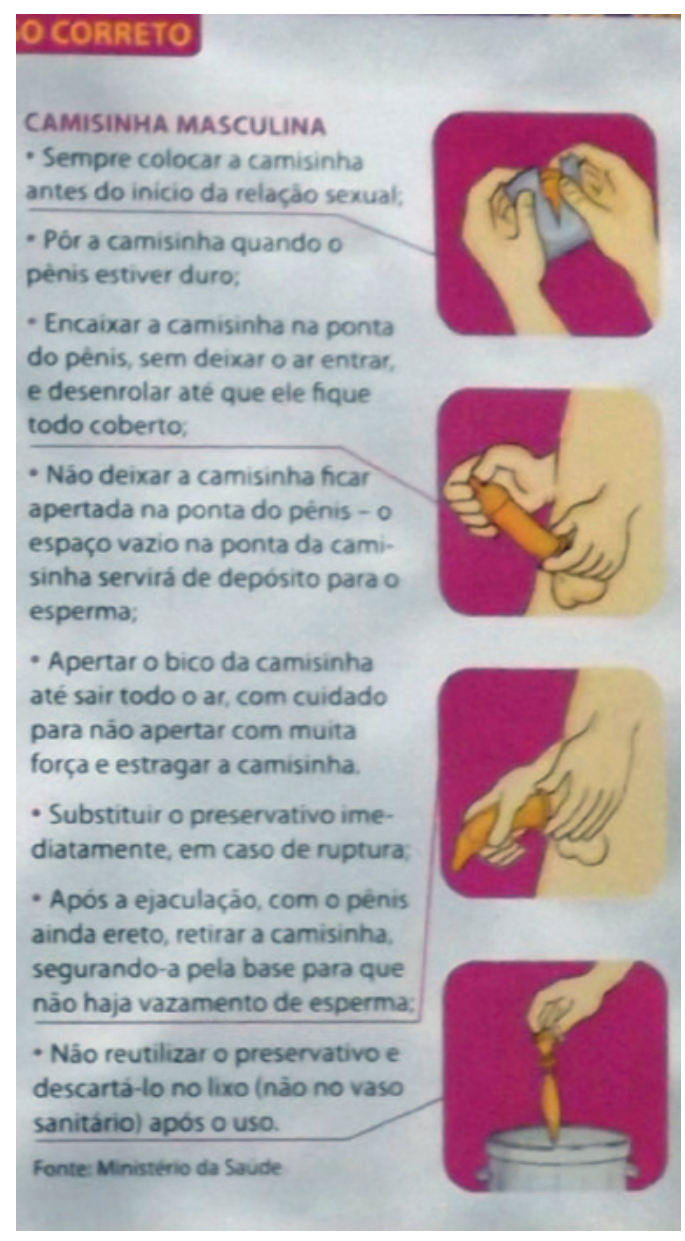

Figura 17 : SPP do uso correto do preservativo masculino (artefatos B, C e E)

Essa visão contraditória entre 'representação verbo-visual mal planejada' e relativa 'eficiência da SPP' parece estar relacionada com a experiência prévia da noção do uso do preservativo masculino ser maior entre os receptores, sendotambémmais frequente a socialização de informações pela mídia. E, segundo os receptores do sexo masculino, facilitava essa realidade, visto o relato que sem o uso dos blocos de texto complementares, essa ação seria menos compreensível.

Considerando que esses artefatos são distribuídos por vezes de forma aleatória, não necessariamente contemplando seu públicoalvo, isso reforça a noção do uso do design da informação para complementação das práticas configurativas das composições gráficas.

Segundo Silva e Coutinho (2010), a aproximação dos repertórios cognitivos entre os protagonistas da atividade comunicacional, facilita o processo de interpretação ali originado. Em outras palavras,isso aumentaria a eficiência dos atributos sintáticos e semânticos dos elementos e facilitaria a interpretação do conteúdo de forma mais generalizada, considerando o uso do preservativo masculino como uma prática de entendimento 'universalizado'.

Em contrapartida, as SPPs do uso do preservativo feminino, presente nos artefatos A e E (figuras 17 e 18), mostraram-se ineficazes 
para todos os receptores do sexo feminino. O texto complementar buscou dar mais detalhes para facilitar a ação, porém esse suporte verbal extra não foi representado graficamente. As mulheres relataram ter uma noção do uso, mas que possivelmente não conseguiriam executá-lo na prática.

Eu nunca usei preservativo feminino [...] dizem até que é mais seguro, mas além deu não saber usar eu precisaria ver tipo aqueles moldes físico para entender melhor. - fala do receptor D

Talvez da primeira vez eu não saberia usar direito só de ver as ilustrações, mas com o tempo eu ia aprendendo [...] teria que treinar. - fala do receptor E

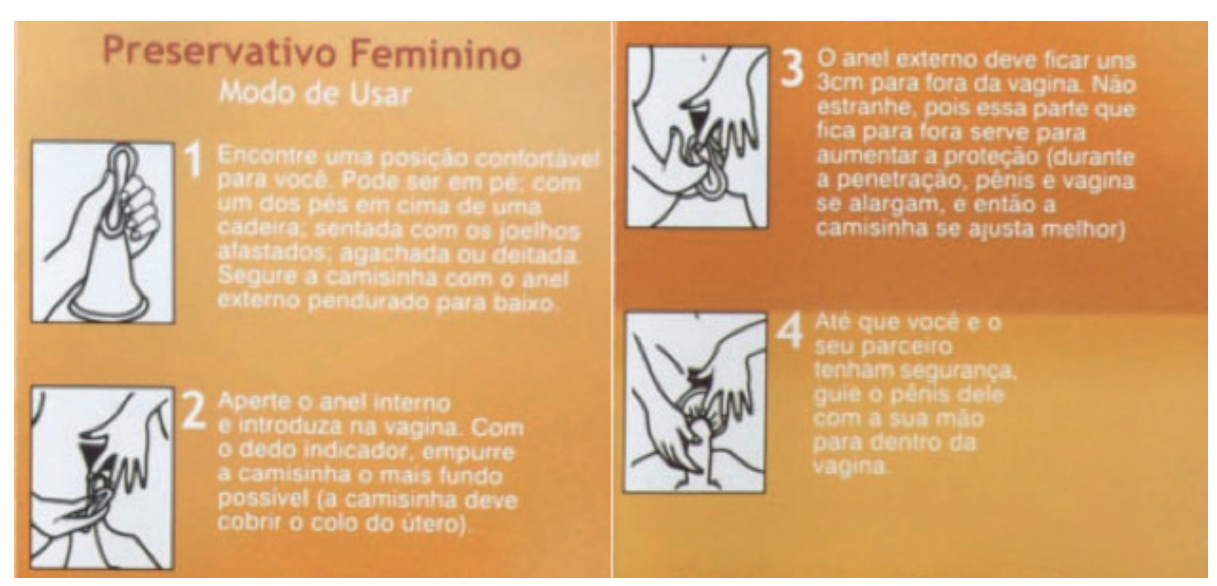

Figura 18 : SPP do uso correto do preservativo feminino (artefato A, disposição original alterada para horizontal)

Da mesma forma, a presença da SPP no artefato E não sanou os ruídos do anterior. Aliás, o uso de cores e a leve redução da área de apresentação do texto e imagens, causaram ainda menos identificação com os receptores. 


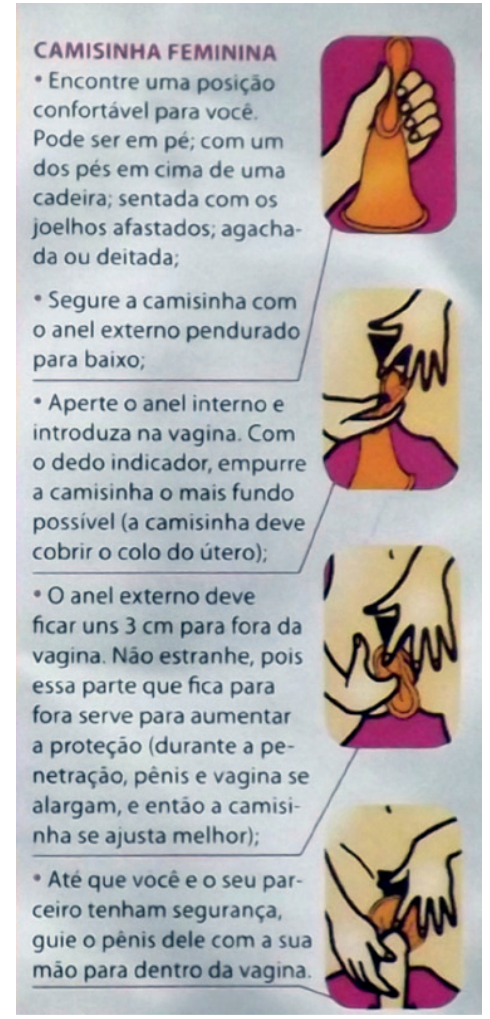

Figura 19 : SPP do uso correto do preservativo feminino (artefato E)

Em relação a SPP presente no artefato B (figura 19), sua duocromia, melhor definição e traços da ilustração pareceram beneficiar a compreensão da ação, sendo a relação entre texto e imagem mais suscinta e diretamente atrelada. O acréscimo de um passo extra possibilitou essa afirmação.

Nesse folder tá melhor de entender como funciona o uso do preservativo feminino [...] as imagens estão bem nítidas. - fala do receptor $\mathrm{F}$

\section{A CAMISINHA FEMININA TAMBÉM PROTEGE VOCÊ.}

\section{0 preservativo feminino garante a você o poder de decisão na hora da relação. Além de ser mais uma} opção segura de prevenir doenças sexualmente transmissiveis, a aids e a gravidez não planejada.

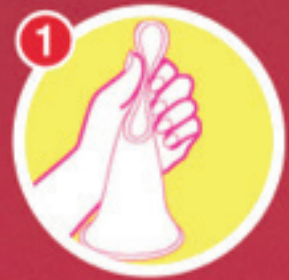

Retire o preservativo

da embalagem e

segure a argola

interna com o polegar e o dedo indicador.

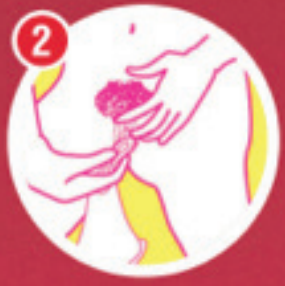

Aperte a argola e a introduza na vagina, empurrando com 0 dedo indicador.

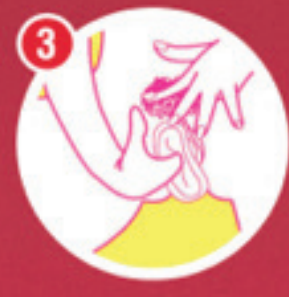

A argola externa deve car para fora da

vagina.

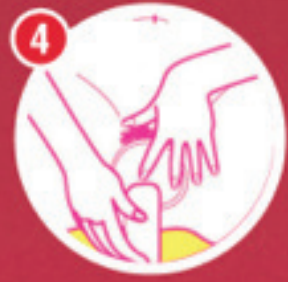

No momento da penetraçăo, segure a argola externa com uma das mãos.

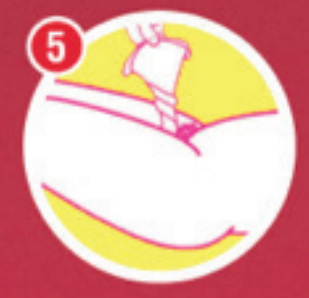

Após a relaçăo torça a argola externa e retire o preservativo com cuidado. Jogue no lixo.

Figura 20 : SPP do uso correto do preservativo feminino (artefato B) 
No que se refere às SSPs, Spinilo (2000) relata que a imagem é definida pelo conjunto de sinais gráficos que representam 'entidades' e 'efêmeros efeitos visuais', sendo associados ao real ou àquilo que se é imaginado. Assim, resgatam-se as afirmações de Goldsmith (1980), nas quais a dimensão da coesão de uma imagem é essencial para a sua interpretação. Ou seja, qualquer área de uma imagem pode ser vista como tendo uma identidade particular, mesmo essa identidade não sendo compreensível por quem observa. Pode-se dizer que por meio da coesão visual, os receptores foram capazes de identificar e diferenciar elementos da realidade, com as exceções já explanadas.

Outra ilustração de baixa compreensão foi a representação para utilização da barreira de látex para prática do sexo oral (figura 21). O receptor tem que fazer uma relação entre os minúsculos ícones das tesouras e dos pontilhados para saber que a ilustração da esquerda representa a instrução do corte em duas direções do preservativo masculino (representado ao centro) para prática do sexo oral feminino, também destacando seu uso para proteção de outras regiões. Já a imagem da direita, tenta ilustrar o correto posicionamento do instrumento 'talhado', resultante da primeira ação. Vale salientar que uma participante achou a informação irrelevante e sentiu-se constrangida, relatando que jamais se veria numa situação dessa para utilizar a barreira.

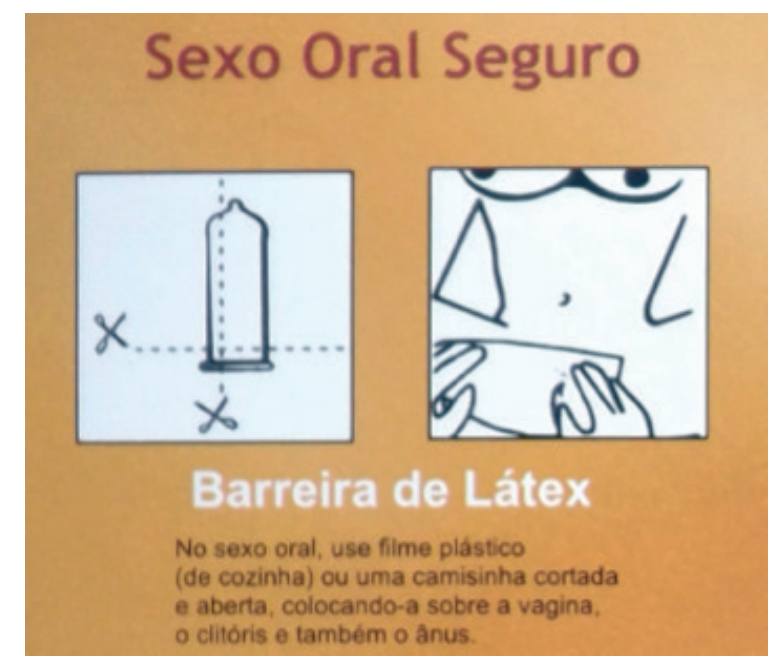

Figura 21 : SPP do uso correto do preservativo feminino

Já o artefato voltado à população Afro-Brasileira (C), tentou aproximar-se do contexto com o uso de uma linguagem verbopictórica pouco usual para pessoas não-praticantes dessas religiões. Os receptores reconhecem que sequer conseguem identificar as 'entidades' representadas pelas ilustrações e tampouco contextualizar, mentalmente, as circunstâncias em que as informações podemser úteis, mas foram atraídos pela 'curiosidade'. 
Sendo assim, o impresso, de certa forma, parece mais levantar questões do que sanar dúvidas, tendo o foco na prevenção às DST/ Aids, no contexto dos receptores, suprimido por outro assunto (o das práticas religiosas).Também foi identificado o uso de uma quantidade significativa de texto corrido, incitando práticas de prevenção em rituais com o uso de lâminas, quando poderiam ser melhores representadas com o auxílio pictórico.No entanto, é inconclusivo o quão eficiente seria a mensagem, caso o impresso fosse confrontado com a realidade de pessoas praticantes dessas religiões.

Resgata-se a afirmação de Twyman (1985) de que o contexto cultural é fator essencial para compreensão visual. A concepção popular na qual as imagens pictóricas são mais eficientes por serem supostamente compreendidas universalmente, é facilmente refutada quando observam-se as convenções pictóricas através de diferentes culturas.

E por fim, o artefato D, embora tenha sido apontado pelos receptores como o visualmente menos atraente, foi um dos preferidos. Essa relação contraditória possivelmente foi causada pelas inéditas informações que só eram abordadas de forma aprofundada neste artefato (Hepatites Virais). A composição também apresentou uma ilustração não compreensível pelos receptores (figura 22), pois utilizou uma foto de indivíduos fazendo uso do crack, e no texto fala sobre o uso de drogas e compartilhamentos de agulhas e seringas.

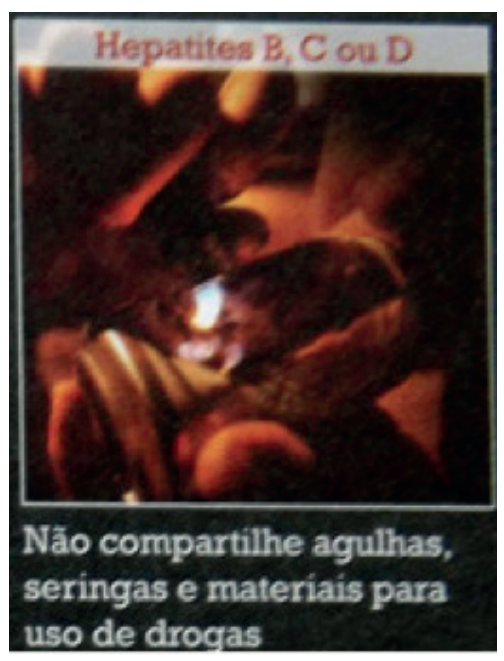

Figura 22 : Ilustração presente no artefato D

Outros pontos também comentados pelos receptores dizem respeito ao uso geral de cores e texturas como fundo nos artefatos e sua relação com os tipos de fontes utilizados, que por vezes dificultava a leiturabilidade das informações.

Os ruídos de interpretação, identificados nas mensagens, geralmente estavam ligados aos aspectos sintáticos, o que Waechter (2008) classifica como 'características visuais', que, por consequência, afetavam os aspectos semânticos das mensagens. 
Nesse sentido, como relatam Paúl \& Fonseca (2001), é essencial a adaptação de programas de intervenção em detrimento às necessidades específicas das populações as quais se destinam às campanhas de IEC, além da articulação entre informação e comportamentos, sendo subjacente a maioria das ações.

Dessa forma, o designer da informação pode valer-se de conhecimentos correlatos às necessidades em questão e buscar equilíbrio entre as polaridades do técnico e semântico para projetar os artefatos como resultado da interação com o processo sociotécnico.

\section{Considerações finais}

Em termos gerais, a configuração dos elementos da LG no planejamento e desenvolvimento dos impressosfoiabordada de forma eficiente na maioria dos impressos. Do ponto de vista do design da informação, a utilização da LGV mostrou-se mais eficaz e com um menor índice de dubiedades cognitivas do que as demais, com algumas exceções.

Em relação ao uso da LGP, geralmente estava associado com questões estéticas, exigindo pouco esforço interpretativo dos receptores, sendo relacionada com questões de complemento visual. De certa forma, pode-se concluir que as ilustrações mostraram-se eficazes no sentido de preencher uma função comunicativa na associação simbólica entre os repertórios dos receptores.

Sob o prisma do design da informação, a LGP mostrou-se por vezes ineficiente, sob o aspecto de não possuir uma carga informacional justificada que tivesse uma relação de aumento da compreensibilidade do conteúdo como um todo, por exemplo, nos momentos que foi utilizada 'meramente' como apelo estético.

Acerca da LGE, caracterizada pelas SPPs, parece necessitar de um aprofundamento e possível reestruturamento nos passos para uma otimização visual e interpretativa, possibilitando assim, equilíbrio no uso dos elementos e seus atributos para cristalização de conhecimentos e adequação de novas condutas pelos participantes frente às DST/Aids.Acredita-se assim, que o uso da Linguagem Gráfica nos artefatos que se mostraram com conteúdo de melhor planejamento, influiram sobre as condutas e comportamentos preventivos dos receptores frente às DST/Aids.

No decorrer dos Grupos Focais, notou-se um equilíbrio na preferência dos receptores entre os artefatos bem planejados, do ponto de vista do design da informação, com os nem tanto. Sendo assim, quando um receptor preferia um artefato, primordialmente pelo seu visual, este necessariamente, buscava complementar a carênciade informações na escolha de um segundo artefato.

A questão é, porque os materiais visualmente menos atraentes tiveram uma preferência equilibrada entre os receptores? A possível respostaé que os impressos visualmente mais atraentes tentavam abordar os assuntos, 
de forma pausada, para que desse tempo ao receptor de refletir sobre aquele determinado contexto até ele se deparar com outro artefato.

O que ocasionava uma quantidade de informações mais selecionadas e de menor extensão, possibilitando uma melhor configuração do conteúdo. Assim, imagina-se que uma pequena euforia gerada pela quantidade de artefatosno momento do manuseio e escolha pelos receptores, tenha causado esse equilíbrio nas preferências. Mas é uma hipótese que deve ser experimentada para conclusões mais precisas.

Todavia, faz-se necessário a integração de metodologias contributivas sob os pressupostos do Design da Informação, que fizeram-se intrínsecos à problemática abordada. Desta forma, buscar aporte de conhecimentos correlatos, baseados em formas de projetar e pensar de forma divergente para soluções convergentes,permitiria vislumbrar determinantes que vão além de conteúdos simplistas e fadigantes encontrados na maioria dos artefatos. Almejando-se assim, a produção e circulação de produtos informacionais qualificados que tragam resultados e mudanças positivas para sociedade.

\section{Referências}

BONSIEPE, G. (2011). Design, cultura e sociedade. São Paulo: Blucher.

BARdin, L. 2009.Análise de Conteúdo. Trad. Luís Antero Reto e Augusto Pinheiro. Lisboa: Edições 70.

BRASIL. M. s. (2002). As carta de Promoção à Saúde. Brasilia. Disponível em: <http://bvsms.saude.gov.br/bvs/publicacoes/cartas_promocao.pdf>. Acesso em: 07/05/2012.

(1998). Conselho Nacional de Ética em Pesquisa. Resolução no 196 de 10 de outubro de 1996. Diretrizes e normas reguladoras de pesquisa envolvendo seres humanos. Cadernos de Ética em Pesquisa. Comissão Nacional de Ética em Pesquisa (CONEP), ano I, $\mathrm{n}^{\mathrm{o}} 1$, jul.

Coutinho, s. G. (2006). Design da informação para educação. Revista Brasileira de Design da Informação, v.3 -1/2, p. 49-60.

DALl'AGNOL, C. M.; TRENCH, M. H. (1999). Grupos Focais como estratégia metodológica em pesquisas na enfermagem. Revista Gaúcha de Enfermagem, Porto Alegre, v.20, n.1: 5-25.

GOLDSMith, E. 1980. Comprehensibility of illustration - an analytical model. Information Design Journal, vol. 1: 204-213.

PAÚl, C.; FOnseCA, A. M. (2001). Psicossociologia da saúde. Lisboa: Climepsi editores. ROZEMBERG, B. (2012). Roteiro para análise de material impresso de educação/comunicação em saúde. Centro de Estudos em Saúde do Trabalhador e Ecologia Humana. Escola Nacional de Saúde Pública Sérgio Arouca, Fiocruz, RJ.

(2002). Participação comunitária em programas de promoção em saúde: elementos para uma avaliação crítica de metas e pressupostos. In: MCS Minayo \& AC Miranda (orgs.). Saúde e ambiente sustentável: estreitando nós. Fiocruz, Rio 
de Janeiro: 191-199.

SAnTos, A. K. (2003). Análise do processo comunicativo mediado por impressos: 0 ponto de vista dos atores dos Programas de Saúde do Trabalhador. Rio de Janeiro, Fundação Osvaldo Cruz, Escola Nacional de Saúde Pública.

SESDF, SECRETARIA DE ESTADO DE SAÚdE DO DISTRITO FEDERAL. (2012). Informação, Educação e Comunicação (IEC). Disponível em: < http://www.saude.df. gov.br/003/00301009.asp?ttCD_CHAVE=23794>. Acesso em: 21 ago. 2012. SILVA, J. F. L.; COUTINHO, S. G. (2010). Esquemas gráficos para informar: a Linguagem Gráfica Esquemática na produção e utilização de livros didáticos infantis na cidade de Recife. Anais do $9^{\circ}$ Congresso Brasileiro de Pesquisa e Desenvolvimento em Design, São Paulo.

SPINILlo, C. (2000). An analytical approach to procedural pictorialsequences. Tese de doutorado não publicada. Departamento de Tipografia Comunicação Gráfica. Universidade de Reading, Grã-Bretanha.

TWYMAN, M. (2002). Further thoughts on a schema for describing graphic language. Proceedings of the1st Internacional Conference on Typography \& Visual Communication History, Theory, Education. University of Macedonia Press, Thessalonniki, Greece.

(1985). Using pictorial language: a discussion of the dimensions of the problem. In: T. M. Dufty and R. Waller (eds.) Designing usable texts.Orlando, Florida: Academic Press, p. 245-312.

WAECHTER, H.N. (2008). Um modelo experimental para a observação da recepção de mensagens em meios impressos.Triades, Rio de Janeiro: Puc-Rio, Out. 2008.

\section{Sobre os autores}

\section{Ranielder Fábio de Freitas}

$<$ ranielderfabio@hotmail.com>

Graduado em Design pela Faculdades Nordeste - Fanor; doutorando em Design - Linha de Pesquisa emDesign da Informação pela Universidade Federal de Pernambuco - UFPE; Integrante do Grupo de Pesquisa de Design da Informação (CNPq).

\section{Hans da Nóbrega Waechter}

$<$ hnwaechter@terra.com.br>

Graduado em Comunicação Visual pela Universidade Federal de Pernambuco - UFPE; mestre e doutor em Comunicação Audiovisual pela Universidade Autônoma de Barcelona UAB - Espanha; docente e coordenador do bacharelado em Design da UFPE; docente do Programa de Pós-graduação em design da UFPE e Líder do Grupo de Pesquisa em Design da Informação (CNPq).

\section{Solange Galvão Coutinho}

<solangecoutinho@globo.com>

Graduada em Comunicação Visual; PhD em Typography \& Graphic Communication - University of Reading; Professora Associado 1 do Curso de Design e do Programa de Pós-Graduação em Design 
da Universidade Federal de Pernambuco - UFPE; pesquisadora do Centre de Recherche Images,Cultures et Cognitions (CRICC), Paris 1 - Pantheon Sorbonne e Líder do Grupo de Pesquisa em Design da Informação (CNPq).

Artigo recebido em 22 abr. 2014, aprovado em 18 jun. 2014. 